Ortega-Álvarez, R., R. Calderón-Parra, U. Martínez Molina, F. Martínez Molina, G. Martínez Molina, Y. Martínez Molina, A. Martínez Villagrán, J. Martínez Freire, R. Vásquez Robles, D. García Loaeza, J. Martínez García, S. García Loaeza, N. I. Garduño López, and L. A. Sánchez-González. 2020. Updating the distribution of the Sierra Madre Sparrow Xenospiza baileyi across central Mexico: historical records, new localities, and conservation perspectives. Avian Conservation and Ecology 15(1):15. https://doi.org/10.5751/ACE-01573-150115

Copyright $(2020$ by the author(s). Published here under license by the Resilience Alliance.

Research Paper

\title{
Updating the distribution of the Sierra Madre Sparrow Xenospiza baileyi across central Mexico: historical records, new localities, and conservation perspectives
}

\author{
Rubén Ortega-Álvarez ${ }^{1}$, Rafael Calderón-Parra ${ }^{2}$, Ulises Martínez Molina ${ }^{2}$, Fredy Martínez Molina ${ }^{2}$, Gabriel Martínez Molina ${ }^{2}$, \\ Yuridia Martínez Molina ${ }^{2}$, Agustín Martínez Villagrán ${ }^{2}$, Josué Martínez Freire ${ }^{2}$, Rocío Vásquez Robles ${ }^{2}$, Delfino García Loaeza ${ }^{2}$, \\ Jaciel Martínez García ${ }^{2}$, Sarai García Loaeza ${ }^{2}$, Nancy Isabel Garduño López ${ }^{2}$ and Luis A. Sánchez-González ${ }^{1}$ \\ ${ }^{1}$ Museo de Zoología "Alfonso L. Herrera," Departamento de Biología Evolutiva, Facultad de Ciencias, Universidad Nacional \\ Autónoma de México, Ciudad de México, México, ${ }^{2}$ Brigada de Monitoreo Biológico Milpa Alta, San Pablo Oztotepec, Milpa Alta, \\ Ciudad de México, México
}

\begin{abstract}
The Sierra Madre Sparrow (Xenospiza baileyi) is an endangered species microendemic to subalpine grasslands of central and northwestern Mexico. Given that land use change is highly dynamic in central Mexico, there is a need for a continuous monitoring of the distribution and conservation status of the species across the region. We here update the distribution of the Sierra Madre Sparrow by surveying the historical sites where the species is known to occur, verifying records from a citizen science database, and identifying potential habitat in the region to find new localities for the species. We also highlight main local threats and discuss potential conservation activities for the sites where we recorded the species. We found that all historical sites are still inhabited by the species and we identified new localities for the Sierra Madre Sparrow. Each locality presents particular threats for the conservation of the species. Common threats to all sites include agriculture and land owners' unawareness about the presence of the species. Particular attention should be focused on providing management guidelines for agricultural practices in the area. Special efforts must be directed to engaging communities into conserving and monitoring subalpine grasslands. Much work should be done to define and apply conservation strategies in cooperation with local governments, institutions, and communities. The identification of new localities for the species reveals the need to expand research beyond traditional study and bird-watching sites.
\end{abstract}

\section{Mise à jour de la répartition du Bruant des sierras Xenospiza baileyi dans le centre du Mexique : mentions historiques, nouveaux sites et perspectives de conservation}

RÉSUMÉ. Le Bruant des sierras (Xenospiza baileyi) est une espèce en voie de disparition microendémique des prairies subalpines du centre et du nord-ouest du Mexique. Le changement dans l'utilisation des terres étant très dynamique dans le centre du Mexique, il importe de faire un suivi continu de la répartition et du statut de conservation de l'espèce dans la région. Nous avons mis à jour la répartition du Bruant des sierras en revisitant les sites historiques de présence de l'espèce, vérifiant les mentions provenant d'une base de données issue de science participative et identifiant des milieux potentiels dans la région afin d'y de trouver de nouveaux sites pour l'espèce. Nous énumérons les menaces locales et décrivons les activités de conservation qu'il est possible de mettre en place aux sites où l'espèce a été observée. Nous avons constaté que tous les sites historiques sont encore occupés par le Bruant des sierras et avons découvert de nouveaux sites de présence. Chaque site présente des menaces particulières pour la conservation de l'espèce. L'agriculture et l'ignorance des propriétaires fonciers quant à la présence de l'espèce sont des menaces communes à tous les sites. Une attention particulière devrait être portée à fournir des directives d'aménagement ciblant les pratiques agricoles dans le secteur. Des efforts spéciaux devraient être destinés aux communautés afin de les engager dans la conservation et le suivi des prairies subalpines. Enfin, il faudrait définir et appliquer les stratégies de conservation en coopération avec les gouvernements, les institutions et les communautés locales. La découverte de nouveaux sites pour l'espèce révèle l'importance d'étendre la recherche au-delà des sites d'étude traditionnels et des sites d'observation d'oiseaux des citoyens.

Key Words: agriculture; cattle grazing; endangered bird; endemic species; Mexico City

\section{INTRODUCTION}

The Sierra Madre Sparrow (Xenospiza baileyi) is a microendemic species of Mexico (Meléndez-Herrada et al. 2016) with a range highly restricted to some scattered localities in the Valley of Mexico and western Durango, in the highlands of central and northwestern Mexico, respectively (Oliveras de Ita and Gómez de Silva 2002, Oliveras de Ita and Rojas-Soto 2006, MartínezGuerrero et al. 2018). Its major population is located in the southern highlands of Mexico City, central Mexico (Berlanga et al. 2009). This species is a habitat specialist, depending on subalpine grasslands for its life cycle (Cabrera-García et al. 2006, 
Oliveras de Ita and Gómez de Silva 2007). In central Mexico, subalpine grasslands range from 3000 to $4300 \mathrm{~m}$ a.s.l. and are dominated by Calamagrostis, Muhlenbergia, Stipa, and Festuca (Rzedowski and Rzedowski 2005).

Population growth, urban development, and agricultural sprawling have severely impacted central Mexico (CONABIO and SEDEMA 2016). These threats have also affected subalpine grasslands, which show a destruction trend of 22 ha per year (Vázquez de la Torre 2015). Habitat conversion and devastation have been highlighted as the main threats for the conservation of the Sierra Madre Sparrow (Oliveras de Ita and Gómez de Silva 2007, BirdLife International 2017). As a result, the species has been classified as endangered by both the IUCN (BirdLife International 2017) and the Mexican Government (SEMARNAT 2010).

Given that most of the records of the Sierra Madre Sparrow have been obtained at La Cima and Llano de Morales in southern Mexico City (Berlanga et al. 2015, Gómez de Silva and Oliveras de Ita 2016), conservation initiatives for the species have been mainly focused on the populations at these two localities. Other populations in different sites have received little consideration, probably because of the fact that records are scarce, unverified, or old.

Although the Sierra Madre Sparrow has a highly restricted range, we are not aware of any study searching for all recorded populations of the species across the region using a systematic procedure. Most records of the species in central Mexico come from a few popular spots visited by birdwatchers (eBird 2019) and from site-specific studies at La Cima (Oliveras de Ita 2002, 2011). Although previous research has estimated the distribution of the species using ecological niche modeling methods (González Abraham 2000, Navarro-Sigüenza and Peterson 2007, Vázquez de la Torre 2015), there have been no field surveys confirming the presence of the Sierra Madre Sparrow across environmentally suitable areas in central Mexico. Given that land use change associated with agricultural and urban sprawl is rapidly occurring in the area (CONABIO and SEDEMA 2016), there is a need for a continuous monitoring of the distribution status of the species across the region. In addition, no efforts have focused on maintaining an updated assessment of the regional distribution of the species. This information however, is fundamental for monitoring and determining the conservation status of the Sierra Madre Sparrow, estimating the habitat conversion trend, identifying conservation priorities, and evaluating the impact of management actions for its preservation (Nichols and Williams 2006, Jones 2011, Ortega-Álvarez et al. 2015).

In this study we updated the distribution of the Sierra Madre Sparrow through an extensive search across central Mexico. We visited the historical sites where the species is known to occur to determine if the species is still present in such areas. In addition, we verified relatively recent records from a citizen science database (Sullivan et al. 2009, eBird 2019), and used updated satellite images to identify potential habitat in the region to find new localities for the species. Finally, we highlight main local threats and discuss potential strategies and management activities for each site where the species was recorded. Results in our study may provide critical information to foster conservation actions for the Sierra Madre Sparrow in the region.

\section{METHODS}

\section{Study area}

We focused our surveys on the subalpine grasslands located in southern Mexico City, northern Morelos, and southern Mexico State, in the highlands of the Transvolcanic Belt of central Mexico (Fig. 1), where the Sierra Madre Sparrow is known to occur (Gómez de Silva and Oliveras de Ita 2016). Natural ecosystems throughout the region include oak, pine, fir, and mixed forests, wetlands, shrublands, and subalpine grasslands, all of which are under severe human pressure by the surrounding urban settlements (CONABIO and SEDEMA 2016) and agricultural lands (Cabrera-García 2006, CONABIO and SEDEMA 2016). Remaining natural ecosystems in the region are mostly restricted to high elevations, because the volcanic mountains have acted as a natural barrier for agricultural and urban sprawl (Arriaga et al. 2000).

Fig. 1. Survey sites for searching the Sierra Madre Sparrow (Xenospiza baileyi) across central Mexico. Numbers represent different localities and circles denote the presence of the species in the site. (a) Mexico City, (b) State of Mexico, (c) Morelos, (1) Xalatlaco, (2) Ex-Cañada Seca Park, (3) road to El Capulín, (4) El Capulín, (5) Ajusco road, (6) La Rufina, (7) Rancho Tres Vientos, (8) Las Maravillas Park, (9) asphalt factory, (10) La Cima, (11) Tres Marías, (12) road from San Juan Tlacotenco to Coajomulco, (13) Llano de Morales, (14) Llano de Otlayuca, (15) slope of Ololica Volcano, (16) Tlaxcaltenco, (17) CICS Milpa Alta, (18) Xocho Volcano.

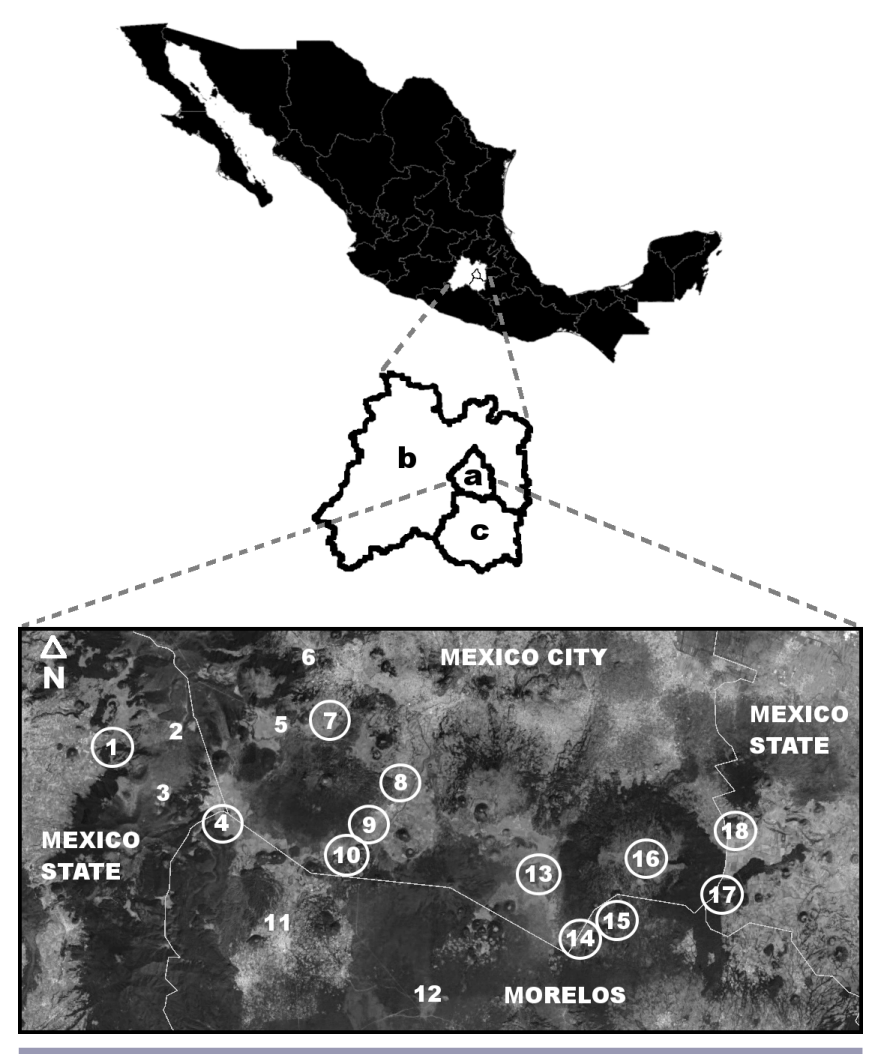


Officially protected natural areas with subalpine grasslands in the region include the Cumbres del Ajusco National Park (Mexico City), the Tepozteco National Park (Morelos), and the Chichinautzin Biological Corridor (Mexico City, Morelos, Mexico State). However, most records of the Sierra Madre Sparrow have been obtained in nonprotected areas, within lands owned by rural and indigenous communities of Mexico City (i.e., San Pablo Oztotepec, San Miguel Topilejo), Mexico State (i.e., Xalatlaco), and Morelos (i.e., El Capulín, San Juan Tlacotenco; Oliveras de Ita and Gómez de Silva 2002, Cabrera-García et al. 2006, Berlanga et al. 2009, 2015).

\section{Historical records}

We reviewed literature (scientific papers, thesis) and searched in citizen science databases such as eBird (2019) to compile all localities where the Sierra Madre Sparrow has been previously observed. In addition, we conducted field surveys to search for the Sierra Madre Sparrow in historical sites where the species has been recorded, which allowed us both to verify and update its presence in these areas.

\section{Data collection}

We conducted fieldwork in the region searching for the Sierra Madre Sparrow with the participation of local community members, i.e., San Pablo Oztotepec, Milpa Alta, who have been involved in community-based bird monitoring projects (for more details see Berlanga et al. 2015 and Ortega-Álvarez et al. 2015). We looked for the species in sites where it has been historically recorded, as well as in the spots where eBird users have observed the species. In addition, we used updated satellite images (from Google Earth Pro), as well as potential distribution maps (González Abraham 2000, Navarro-Sigüenza and Peterson 2007, Vázquez de la Torre 2015), to visually identify areas with suitable habitat, i.e., subalpine grasslands, where the Sierra Madre Sparrow might occur but has not been previously recorded.

After identifying areas with suitable habitat and selecting both historical and potential sites, we visited each locality and searched for the species following the methodology proposed by Oliveras de Ita and Rojas-Soto (2006): (a) listening and searching using binoculars during a 10-min period; then (b) performing playbacks of the songs and calls during a 10-min period; and (c) walking throughout the site. The first two steps were performed within unfixed-radius stationary survey points located at the center of patches with suitable habitat. Playbacks were paused every three minutes to facilitate detection. If the species was not detected after the first two steps, walking was performed throughout the surveyed subalpine grassland patch. We concluded surveys at each site as soon as the species was detected or when the site was completely traveled by the observers. If the site consisted of a large patch of subalpine grassland, we repeated on multiple occasions the methodology until the species was detected, or when the whole site was surveyed. Several observers simultaneously searched for the species during surveys, increasing the probabilities of detection. We performed surveys during the peak of the breeding season (915 July 2019), when singing males are more conspicuous and responsive to playbacks (Oliveras de Ita and Rojas-Soto 2006, Berlanga et al. 2009). All surveyors, including local community members, were highly trained in visual and aural identification of the Sierra Madre Sparrow. Given that most of the subalpine grasslands in the region have been destroyed or severely degraded by land use change, we were able to survey most of the areas that are still covered by this habitat, including the largest patches. This method allowed us to perform a cost- and time-efficient first-pass survey to determine if the species was present at each study site, which was the main objective of this study (Table 1).

Following field surveys, we assessed the relative abundance of the Sierra Madre Sparrow for each study site (Table 1) by using these categories (based on Howell and Webb 1995): (a) common, when the species is usually detected at the site, often in large numbers; (b) fairly common, when usually detected at the site, but in small numbers, (c) uncommon, when it is unlikely to be detected, and then only in small numbers, and (d) rare, when it is present but not frequently detected. For assigning a relative abundance category for each site, we considered the following (Table 1): (a) the survey period when we detected the species, assuming that relative abundance might be greater if the species was observed during the first steps of surveys, (b) the number of individuals that we detected because more detected individuals might be related with higher relative abundance, (c) the size of the grassland patch for each site as reported by other studies (Sánchez-González et al. 2019), given that the presence of a larger subalpine grassland patch might increase the relative abundance of the species, (d) the frequency of reports of the species from eBird (2019), which provides information on how often a species is reported on complete checklists within a specified date range and region, and (e) our previous experience on detecting the species at each site. The value for the frequency of reports from eBird (2019) was calculated by averaging the frequency of all months, ranging from January to December from 1900 to 2020 for each study site. Frequency reports from eBird were not available for poorly studied sites, and for those where we recorded the Sierra Madre Sparrow for the first time (Table 2).

\section{RESULTS}

We visited 18 sites across Central Mexico (Fig. 1). In four of these sites, the species has been previously recorded (Table 2). Our surveys showed that the Sierra Madre Sparrow still inhabits each of these historical sites (Table 3), including Llano de Morales, Mexico City (Cabrera-García 2006), La Cima, Mexico City (Oliveras de Ita and Gómez de Silva 2007), Xalatlaco, Mexico State (Oliveras de Ita and Gómez de Silva 2002), and El Capulín, Morelos (Cabrera-García 2004).

We also verified the presence of the species in sites indicated in eBird (2019; Table 2). However, we discarded those sites that were geographically misplaced or referred to broad areas, such as Valley of Mexico and Milpa Alta, because it was not possible to identify the precise location where the sighting was made. We also did not take into account records from highly urbanized areas with unsuitable habitat for the species within Toluca and Mexico City, as well as records from the Lerma Marshes, because all of these may pertain to the highly similar Song Sparrow (Melospiza melodia) or Lincoln's Sparrow (Melospiza lincolnii). We also visited a location reported in eBird along the road connecting San Juan Tlacotenco and Coajomulco, but we did not find evidence nor suitable habitat for the species to occur (Table 2). We noticed that most records in eBird were performed by bird-watchers searching for the species in La Cima and Las Maravillas Park located in Mexico City (eBird 2019). Other observations belonged to community-based monitoring and scientific studies that were 
Table 1. Survey effort and relative abundance of the Sierra Madre Sparrow for each site. Name, number of detected individuals, survey period when the individuals were detected, number of observers that performed surveys, survey duration, distance traveled during surveys, number of survey points that were used to detect the species, frequency of reports following eBird, surface of subalpine grassland, and relative abundance of the Sierra Madre Sparrow are specified for each site. First survey period consisted in listening and searching with binoculars; during the second period we performed playbacks for attracting the species. Surveys finished during the period when we detected the species for the first time. As the first and second periods were carried out in a stationary survey point, no distance was travelled during such periods. Travelling was only needed for the third period of the surveys.

\begin{tabular}{|c|c|c|c|c|c|c|c|c|c|}
\hline Site & $\begin{array}{c}\text { Detected } \\
\text { individuals }\end{array}$ & $\begin{array}{l}\text { Survey } \\
\text { period }\end{array}$ & $\begin{array}{c}\text { Number of } \\
\text { observers }\end{array}$ & $\begin{array}{c}\text { Survey } \\
\text { duration }\end{array}$ & $\begin{array}{l}\text { Distance } \\
\text { travelled }\end{array}$ & $\begin{array}{c}\text { Number of } \\
\text { survey points }\end{array}$ & $\begin{array}{l}\text { Frequency of } \\
\text { reports }\end{array}$ & $\begin{array}{c}\text { Grassland } \\
\text { surface (ha) }\end{array}$ & $\begin{array}{c}\text { Relative } \\
\text { abundance }\end{array}$ \\
\hline Llano de Morales & 3 & First & 3 & $10 \mathrm{~min}$ & $0 \mathrm{~m}$ & 1 & Not available & 1792.10 & Common \\
\hline Llano de Otlayuca & 5 & First & 3 & $5 \mathrm{~min}$ & $0 \mathrm{~m}$ & 1 & Not available & 99 & Common \\
\hline El Capulín & 3 & First & 2 & $10 \mathrm{~min}$ & $0 \mathrm{~m}$ & 1 & Not available & 63 & Common \\
\hline Tlaxcaltenco & 1 & First & 2 & $10 \mathrm{~min}$ & $0 \mathrm{~m}$ & 1 & Not available & 119.4 & Fairly common \\
\hline Rancho Tres Vientos & 2 & First & 2 & $10 \mathrm{~min}$ & $0 \mathrm{~m}$ & 1 & Not available & 41 & Fairly common \\
\hline Slope of Ololica Volcano & 1 & Second & 3 & $15 \mathrm{~min}$ & $0 \mathrm{~m}$ & 1 & Not available & 171.4 & Fairly common \\
\hline Las Maravillas Park & 1 & Second & 2 & $20 \mathrm{~min}$ & $0 \mathrm{~m}$ & 1 & 52.5 & 39.4 & Fairly common \\
\hline La Cima & 1 & Second & 2 & $20 \mathrm{~min}$ & $0 \mathrm{~m}$ & 1 & 66.4 & 19 & Fairly common \\
\hline Asphalt factory & 2 & Second & 2 & $20 \mathrm{~min}$ & $0 \mathrm{~m}$ & 1 & Not available & 22 & Fairly common \\
\hline Xalatlaco & 1 & Second & 2 & $20 \mathrm{~min}$ & $0 \mathrm{~m}$ & 1 & Not available & 156 & Uncommon \\
\hline Xocho Volcano & 3 & Second & 11 & $20 \mathrm{~min}$ & $0 \mathrm{~m}$ & 1 & Not available & 27 & Rare \\
\hline CICS Milpa Alta & 2 & Second & 11 & $20 \mathrm{~min}$ & $0 \mathrm{~m}$ & 1 & Not available & 6.8 & Rare \\
\hline Road to El Capulín & 0 & - & 2 & $30 \mathrm{~min}$ & $200 \mathrm{~m}$ & 1 & - & 2 & Undetected \\
\hline Tres Marías & 0 & - & 2 & $30 \mathrm{~min}$ & $100 \mathrm{~m}$ & 1 & - & 2 & Undetected \\
\hline La Rufina & 0 & - & 2 & $30 \mathrm{~min}$ & $150 \mathrm{~m}$ & 1 & - & 1.5 & Undetected \\
\hline Ex-Cañada Seca Park & 0 & - & 2 & $30 \mathrm{~min}$ & $200 \mathrm{~m}$ & 1 & - & 1.5 & Undetected \\
\hline Ajusco Road & 0 & - & 2 & $30 \mathrm{~min}$ & $100 \mathrm{~m}$ & 1 & - & 1 & Undetected \\
\hline Road San Juan & 0 & - & 2 & - & - & 0 & - & 0 & Undetected \\
\hline \multicolumn{10}{|l|}{ Tlacotenco to } \\
\hline Coajomulco & & & & & & & & & \\
\hline
\end{tabular}

Table 2. Surveyed sites for the Sierra Madre Sparrow (Xenospiza baileyi) across central Mexico. The name, state, and the coordinates where the sites are located are specified. Type of sites include historical localities, eBird spots, and localities surveyed because they contained suitable habitat for the species. * Localities where the species was recorded for the first time.

\begin{tabular}{|c|c|c|c|c|c|}
\hline Site & State & Longitude & Latitude & Detection & Type of site \\
\hline La Cima & Mexico City & -99.20056395 & 19.10956647 & Detected & Historical locality; eBird spot \\
\hline Las Maravillas Park & Mexico City & -99.16762202 & 19.15108364 & Detected & eBird spot \\
\hline Asphalt factory & Mexico City & -99.18866531 & 19.12261838 & Detected* & Locality with suitable habitat \\
\hline Rancho Tres Vientos & Mexico City & -99.21520645 & 19.18891274 & Detected* & Locality with suitable habitat \\
\hline La Rufina & Mexico City & -99.23184541 & 19.23228829 & Not detected & Locality with suitable habitat \\
\hline Ajusco Road & Mexico City & -99.24334042 & 19.18673626 & Not detected & Locality with suitable habitat \\
\hline Tlaxcaltenco & Mexico City & -99.00636 & 19.10741 & Detected* & Locality with suitable habitat \\
\hline Llano de Morales & Mexico City & -99.075013 & 19.097115 & Detected & Historical locality; eBird spot \\
\hline CICS Milpa Alta & Mexico State & -98.96194691 & 19.0854595 & Detected* & Locality with suitable habitat \\
\hline Xocho Volcano & Mexico State & -98.95298495 & 19.12317164 & Detected* & Locality with suitable habitat \\
\hline Xalatlaco & Mexico State & -99.35472559 & 19.17240819 & Detected & Historical locality \\
\hline Ex-Cañada Seca Park & Mexico State & -99.31498922 & 19.17872904 & Not detected & Locality with suitable habitat \\
\hline Road to El Capulín & Morelos & -99.32025432 & 19.14160833 & Not detected & Locality with suitable habitat \\
\hline El Capulín & Morelos & -99.28180122 & 19.12759749 & Detected & Historical locality \\
\hline Tres Marías & Morelos & -99.24488556 & 19.06494005 & Not detected & Locality with suitable habitat \\
\hline $\begin{array}{l}\text { Road from San Juan Tlacotenco } \\
\text { to Coajomulco }\end{array}$ & Morelos & -99.14716923 & 19.02345627 & Not detected & eBird spot \\
\hline Llano de Otlayuca & Morelos & -99.0504 & 19.06297 & Detected* & Locality with suitable habitat \\
\hline Slope of Ololica Volcano & Morelos & -99.03001 & 19.06637 & Detected* & Locality with suitable habitat \\
\hline
\end{tabular}

performed within and nearby the subalpine grasslands at Llano de Morales, in Milpa Alta, Mexico City.

We surveyed 12 sites containing suitable habitat but where the species has not been previously recorded (Table 2). We found the presence of the Sierra Madre Sparrow at seven of these sites, three of which are located in Mexico City (asphalt factory, Rancho Tres Vientos, and Tlaxcaltenco), two in Mexico State (CICS Milpa
Alta, Xocho Volcano), and two in Morelos (Llano de Otlayuca, slope of Ololica Volcano; Table 3). Most of our records were performed during the second surveying period (playback period; 7 of 12 sites), which reduced the travel distance needed to detect the species (Table 1). Because the Sierra Madre Sparrow was always efficiently detected during the first two periods of the surveys, we needed a unique survey point at each site where we recorded the species (Table 1). No survey points were located in 
Table 3. Major threats and suggested conservation actions for the Sierra Madre Sparrow (Xenospiza baileyi) at each locality where we detected the species across central Mexico.

\begin{tabular}{|c|c|c|}
\hline Site & Major threats for the species & Conservation action \\
\hline \multirow[t]{3}{*}{ La Cima } & Farming & Determine management guidelines for farming \\
\hline & Forestation of grasslands & Stop forestation programs within the grassland \\
\hline & Vandalism & Engage community and government in surveillance activities \\
\hline \multirow[t]{2}{*}{ Las Maravillas Park } & Community's unawareness about the species presence & Engage community in monitoring and conservation \\
\hline & Leisure activities & Promote leisure activities outside grasslands \\
\hline \multirow[t]{2}{*}{ Asphalt factory } & Urban development & Stop urban development \\
\hline & Citizen's unawareness about the species' presence & Engage private land owners in monitoring and conservation \\
\hline \multirow{3}{*}{ Rancho Tres Vientos } & Urban development & Stop urban development \\
\hline & Farming & Determine management guidelines for farming \\
\hline & Citizen's unawareness about the species' presence & $\begin{array}{l}\text { Engage private land owners in monitoring and conservation } \\
\text { Acquire private land for conservation }\end{array}$ \\
\hline Tlaxcaltenco & Community's unawareness about the species presence & Engage community in monitoring and conservation \\
\hline \multirow[t]{5}{*}{ Llano de Morales } & Farming & Determine management guidelines for farming \\
\hline & Cattle grazing & Regulate cattle grazing \\
\hline & Fire & Address fire management strategies \\
\hline & Community's unawareness about the species' presence & Engage community in monitoring and conservation \\
\hline & Land tenure conflicts & Seek for political mediation and negotiation \\
\hline \multirow[t]{3}{*}{ CICS Milpa Alta } & Farming & Determine management guidelines for farming \\
\hline & Forestation of grasslands & Stop forestation programs in the grassland \\
\hline & Citizen's unawareness about the presence of the species & Engage land owners in monitoring and conservation \\
\hline \multirow[t]{2}{*}{ Xocho Volcano } & Farming & Determine management guidelines for farming \\
\hline & Community's unawareness about the species' presence & Engage community in monitoring and conservation \\
\hline \multirow[t]{5}{*}{ Xalatlaco } & Farming & Determine management guidelines for farming \\
\hline & Cattle grazing & Regulate cattle grazing \\
\hline & Unplanned tourism & Regulate touristic activities in the area \\
\hline & Forestation of grasslands & Stop forestation programs in the grassland \\
\hline & Community's unawareness about the species' presence & Engage community in monitoring and conservation \\
\hline \multirow[t]{2}{*}{ El Capulín } & Farming & Determine management guidelines for farming \\
\hline & Community's unawareness about the species' presence & Engage community in monitoring and conservation \\
\hline \multirow{2}{*}{ Llano de Otlayuca } & Land tenure conflicts & Seek political mediation and negotiation \\
\hline & Community's unawareness about the species' presence & Engage community in monitoring and conservation \\
\hline \multirow[t]{2}{*}{ Slope of Ololica Volcano } & Farming & Determine management guidelines for farming \\
\hline & Community's unawareness about the species' presence & Engage community in monitoring and conservation \\
\hline
\end{tabular}

the road of San Juan Tlacotenco to Coajomulco because we did not find suitable habitat for the species (Table 1).

Relative abundance of the Sierra Madre Sparrow is variable among study sites (Table 1). The species is common in three sites, including Llano de Morales, Llano de Otlayuca, and El Capulín. Among these sites, Llano de Morales is the most important because it contains the largest surface of subalpine grassland across the region. The Sierra Madre Sparrow showed to be fairly common and rare in the sites where we report the species for the first time, with the exception of the Llano de Otlayuca.

\section{DISCUSSION}

We detected the Sierra Madre Sparrow in every single site where it has been historically recorded. However, we observed that its relative abundance varied among surveyed sites. As expected, Llano de Morales is a key place for the conservation of the Sierra Madre Sparrow because it contains the largest patch of subalpine grassland across the region and, following our surveys, the species may be considered as common there. We noted that all sites face severe anthropogenic threats, mainly related to agriculture (Table 3). Although the Sierra Madre Sparrow currently has a quite restricted range and is considered as a globally endangered species, we were able to identify new localities for the species by using both potential distribution maps and satellite photography, highlighting the use of these technologies for conservation purposes, i.e., locating unrecorded populations. Our results suggest that further research is needed beyond the sites where the species has been historically recorded and studied, whereas new records of the species provide insights and opportunities for tackling its conservation and management needs, e.g., acquiring private lands (Table 3 ).

Our observations showed that all of the historical sites still harbor populations of the Sierra Madre Sparrow. Llano de Morales is therefore of prime importance for the species because it contains the largest surface of subalpine grassland across the region and the species is common in the site. Despite this, the best-studied population of the Sierra Madre Sparrow is located at La Cima (Oliveras de Ita 2002, Gómez de Silva and Oliveras de Ita 2016), which is also very popular among bird-watchers (eBird 2019). Nevertheless, the subalpine grassland has been extremely reduced in this site (19 ha), which threatens the local conservation of the species. Clearly, there is an urgent need to expand research beyond La Cima to assess the size and status of other populations of the species across the region. As soon as some of these parameters become available, working with local communities to attend threats would be critical (Cabrera-García and Frias 2004).

Different surveyed localities, including Las Maravillas Park and the asphalt factory, could prove important for the Sierra Madre 
Sparrow. On the one hand, the species is fairly common in both sites, and on the other hand, these sites may act as natural corridors connecting populations from larger grassland patches in the region. Las Maravillas Park has received a lot of attention by bird-watchers in recent years (eBird 2019). In fact, the discovery and exploration of this locality is relatively recent $(\sim$ four years ago), and it has become highly attractive for birdwatching because of good security conditions. The park is close to La Cima $(\sim 5.5 \mathrm{~km})$, which may allow individuals of local populations of the Sierra Madre Sparrow to move among sites. The asphalt factory was one of the sites where we recorded the Sierra Madre Sparrow for the first time. This locality is situated between La Cima and Las Maravillas Park, therefore may also function as a corridor for the species (Cabrera-García 2004, Gómez de Silva and Oliveras de Ita 2016).

Rancho Tres Vientos is found within an area of privately owned lands located in Tlalpan, close to Cumbres del Ajusco National Park (INE 1997). Here, old and large patches of subalpine grassland intermingle with crop fields, farms, and scattered houses. The site is quite interesting for conservation purposes because the species is fairly common and it is the only locality across the region where land might be acquired to protect the habitat for the species. Moreover, the habitat seems to be in good condition for the Sierra Madre Sparrow because it contains large and clustered bunches of grass (Cabrera-García et al. 2006). Grasslands here might be connected with those from La Cima and Las Maravillas Park because they are not far away from each other $(\sim 6.7 \mathrm{~km})$.

New localities for the Sierra Madre Sparrow in Mexico State included the land owned by the Interdisciplinary Center of Health Sciences of the Instituto Politécnico Nacional (CICS Milpa Alta with its Spanish initials) and the crater of the Xocho Volcano. The land of CICS Milpa Alta contains the local campus of the university, which is surrounded by small and scattered highly disturbed subalpine grassland patches, agricultural areas, and pine forests. The species has been unnoticed given that little birdwatching has been performed in the area and the Sierra Madre Sparrow is rare; therefore involvement of this educational institution is necessary to ensure the protection of the local habitat and the population of the Sierra Madre Sparrow.

We detected the Sierra Madre Sparrow at the crater of the Xocho Volcano, representing the easternmost record of the species in the region. We found the species to be rare and restricted to the crater, as its slopes and the surrounding areas are completely dominated by agricultural lands and a few patches of oak and pine forests. Because extinct volcanoes are widespread across the area (Rzedowski and Rzedowski 2005), we suspect that other populations of the Sierra Madre Sparrow might find suitable habitat at their peaks. In fact, the Ololica Volcano is another example of a volcanic locality that acts as a refuge for the sparrow. This volcano is located in Morelos, just at the border with Mexico City. We surveyed two localities there, the Llano de Otlayuca and the slope of the Ololica Volcano, both representing a continuum of the subalpine grasslands of the Llano de Morales. We found the species to be common at Llano de Otlayuca, a plain with large, old, and largely undisturbed subalpine grasslands found in the intersection of the Tepozteco National Park and Milpa Alta. The slope of the Ololica Volcano is adjacent to the Tepozteco National
Park, but land there is owned and managed by the community of Tlalnepantla. Hence, working with communities is imperative to foster the conservation of the species in this area, which is still fairly common in the site.

Because of the socio-political heterogeneity that characterizes the region, each locality presents particular threats for the conservation of the Sierra Madre Sparrow (Table 3). Nevertheless, some threats are common to all sites including land use change for farming practices and land owners' unawareness about the presence of the Sierra Madre Sparrow (Cabrera-García et al. 2006, Berlanga et al. 2015). Thus, major attention should be focused on providing regional management guidelines to achieve a sustainable use of the landscape, specifically by adjusting farming practices, i.e. potato and oat production, and regulating cattle grazing in the area (Cabrera-García 2004). Also, more attention should be made to engaging citizens and communities into conserving and monitoring local subalpine grasslands (Cabrera-García and Frias 2004). Current efforts performed by local community-based monitoring groups are essential for these tasks (Berlanga et al. 2015).

Our assessment of the relative abundance of the Sierra Madre Sparrow might prove useful as a first approach to understand how the population varies among sites across the region. In this sense, urgent conservation actions might be taken in those sites where the species is uncommon and rare, i.e., Xalatlaco, Xocho Volcano, and CICS Milpa Alta, given that the species might be more susceptible to disappearing in the near future. Nevertheless, future studies should focus on performing specific analyses to understand the biotic and abiotic factors that influence the population parameters of the Sierra Madre Sparrow, to define particular actions for preserving the species across central Mexico.

\section{CONCLUSION}

We here provided a wide view of the problems affecting each of the sites inhabited by the Sierra Madre Sparrow across central Mexico. However, more detailed evaluations of the local habitat and threats must be performed to determine site-specific management actions for conserving the species. In this sense, much work must be done to define and apply local conservation strategies in cooperation with local governments, institutions, and communities, given that the region is small but quite heterogeneous from a sociopolitical perspective.

At a regional scale, the habitat of the Sierra Madre Sparrow is mainly threatened by land use conversion promoted by agriculture. Thus, there is an urgent need to define management guidelines for this productive activity, with the aim of conserving the habitat for the species while providing economic revenues for human communities. Because most of the distribution of the Sierra Madre Sparrow lies within communal lands, conservation strategies for the species must include the active participation of local communities when defining management actions, conservation policies, and research agendas. In addition, much governmental work must also be done, as contradictory activities promoted by institutional programs, e.g., forestation programs for the grasslands, reduce the habitat quality for the species and dissuade the trust and participation of local communities in restoring and conserving the grasslands. We believe that it is important to create a regional agenda for conserving the species 
by including the multiple actors that have an impact on the preservation of the grasslands, e.g., communities, governmental institutions, or enterprises, and consider several management actions at multiple scales, e.g. local, regional, and federal.

Although the Sierra Madre Sparrow is an endangered species with a very restricted range, we were able to detect new localities for the species across central Mexico. This reveals the need to focus the research on the sparrow beyond sites that have traditionally received more attention by researchers and bird-watchers. Expanding the known range of the species and having a first assessment on the relative abundance of the species across the region, provides new opportunities for developing conservation strategies involving different actors. Still, further knowledge on the ecology and natural history of the species is required to understand factors enabling it to inhabit unexpected sites across the region. Future research needed for the Sierra Madre Sparrow includes density and occupancy estimations, studies on population dynamics, and movement analyses.

Responses to this article can be read online at: http://www.ace-eco.org/issues/responses.php/1573

\begin{abstract}
Acknowledgments:
We are grateful to the communities of Milpa Alta, particularly to San Pablo Oztotepec, for supporting this project. We thank Francisco Salazar, Marco Castro, Alejandra Flores, Antonio Blancas, and the UNAM for their assistance. We are also thankful to the editors and two anonymous reviewers for their valuable comments that considerably improved this paper. Financial support was received from the Comision Nacional de Áreas Naturales Protegidas (CONANP), through the project "Conservación del Gorrión Serrano y su hábitat en el Tepozteco y Corredor Biológico Chichinautzin," associated with the "Programa para la Protección $y$ Restauración de Ecosistemas y Especies en Riesgo 2019" (PROREST 55657-1158-1-VIII-19).
\end{abstract}

\section{LITERATURE CITED}

Arriaga, L., J. Espinoza, C. Aguilar, E. Martínez, L. Gómez, and E. Loa. 2000. Regiones terrestres prioritarias de México. Comisión Nacional para el Conocimiento y Uso de la Biodiversidad, Distrito Federal, México.

Berlanga, H., R. Ortega-Álvarez, L. A. Sánchez-González, R. Calderón-Parra, V. Rodríguez-Contreras, V. Vargas-Canales, and E. Iñigo-Elias. 2015. Más que un gorrión: participación comunitaria enfocada hacia la comprensión, restauración y conservación del hábitat de Xenospiza baileyi en Milpa Alta, Distrito Federal. Pages 141-157 in R. Ortega-Álvarez, L. A. Sánchez-González, and H. Berlanga-García, editors. Plumas de multitudes: integración comunitaria en el estudio y monitoreo de aves en México. Comisión Nacional para el Conocimiento y Uso de la Biodiversidad, Ciudad de México, México.

Berlanga, H., V. Rodríguez, A. Oliveras de Ita, L. A. SánchezGonzález, and E. Iñigo Elias. 2009. Conservación de hábitat y especies: Los pastizales de montaña y el Gorrión Serrano en México. Biodiversitas 87:11-15.
BirdLife International. 2017. Xenospiza baileyi. The IUCN Red List of Threatened Species 2017. International Union for Conservation of Nature, Cambridge, UK. https://doi. org/10.2305/iucn.uk.2017-3.rlts.t22721153a117856619.en

Cabrera-García, L. 2004. Situación actual y reflexiones sobre la conservación del Gorrión Serrano (Xenospiza baileyi): hacia un futuro prometedor. ParksWatch, Montréal, Québec, Canada.

Cabrera-García, L. 2006. Linking social and ecological dynamics for bird conservation: protecting the endangered Sierra Madre Sparrow in Chichinautzin, Mexico. Dissertation. McGill University, Montréal, Québec, Canada.

Cabrera-García, L., and G. Frias. 2004. Facing bird conservation in conflicted communal lands: a participatory experience towards the Sierra Madre Sparrow habitat conservation. Tenth Biennial Conference of the International Association for the Study of Common Property 2004, Oaxaca, México. [online] URL: https:// dlc.dlib.indiana.edu/dlc/handle/10535/1403

Cabrera-García, L., J. A. Velázquez Montes, and M. E. Escamilla Weinmann. 2006. Identification of priority habitats for conservation of the Sierra Madre Sparrow Xenospiza baileyi in Mexico. Oryx 40:211-217. https://doi.org/10.1017/S0030605306000615

CONABIO and SEDEMA (Comisión Nacional para el Conocimiento y Uso de la Biodiversidad and Secretaría del Medio Ambiente de la Ciudad de México). 2016. La biodiversidad en la Ciudad de México. Volumen 2. Comisión Nacional para el Conocimiento y Uso de la Biodiversidad, Secretaría del Medio Ambiente del Distrito Federal, Ciudad de México, México.

eBird. 2019. eBird: an online database of bird distribution and abundance. eBird, The Cornell Lab of Ornithology, Ithaca, New York, USA.

Gómez de Silva, H., and A. Oliveras de Ita. 2016. El gorrión serrano (Xenospiza baileyi). Pages 418-420 in CONABIO, and SEDEMA, editors. La biodiversidad en la Ciudad de México. CONABIO, SEDEMA, Ciudad de México, México.

González Abraham, C. E. 2000. Identificación de las áreas críticas para la conservación del Gorrión Serrano (Xenospiza baileyi). Universidad Nacional Autónoma de México, Estado de México, México.

Howell, S. N. G., and S. Webb. 1995. A guide to the birds of Mexico and Northern Central America. Oxford University Press, Oxford, $\mathrm{UK}$.

Instituto Nacional de Ecología (INE). 1997. Parques nacionales de México. INE, Ciudad de México, México.

Jones, J. P. G. 2011. Monitoring species abundance and distribution at the landscape scale. Journal of Applied Ecology 48:9-13. https://doi.org/10.1111/j.1365-2664.2010.01917.x

Martínez-Guerrero, J. H., J. Nocedal, D. Sierra-Franco, S. I. Arroyo-Arroyo, and M. E. Pereda-Solís. 2018. New locality of the endangered Sierra Madre Sparrow (Xenospiza baileyi) from the State of Durango, Mexico, and recommendations for its conservation. Acta Zoológica Mexicana 34:1-6. https://doi. org/10.21829/azm.2018.3412115

Meléndez-Herrada, A., H. Gómez de Silva, and R. OrtegaÁlvarez. 2016. Aves. Pages 404-413 in CONABIO, and SEDEMA, 
editors. La biodiversidad en la Ciudad de Mexico. CONABIO, SEDEMA, Ciudad de México, México.

Navarro-Sigüenza, A. G., and A. T. Peterson. 2007. Xenospiza baileyi (Gorrión Serrano) residencia permanente. Distribución potencial, escala 1:1 000 000. Museo de Zoología, Facultad de Ciencias, Universidad Nacional Autónoma de México y University of Kansas, Museum of Natural History, México.

Nichols, J. D., and B. K. Williams. 2006. Monitoring for conservation. Trends in Ecology and Evolution 21:668-673. https:// doi.org/10.1016/j.tree.2006.08.007

Oliveras de Ita, A. 2002. Dinámica poblacional e historia natural del Gorrión Serrano (Xenospiza baileyi). Universidad Nacional Autónoma de México, Distrito Federal, México.

Oliveras de Ita, A. 2011. Estructura genética y distribución del gorrión serrano (Xenospiza baileyi): una especie en peligro de extinción. Universidad Nacional Autónoma de México, Morelia, México.

Oliveras de Ita, A., and H. Gómez de Silva. 2002. Nueva localidad para el Gorrión Serrano (Xenospiza baileyi). Ornitologia Neotropical 13:203-204.

Oliveras de Ita, A., and H. Gómez de Silva. 2007. Territoriality and survivorship of the Sierra Madre sparrow in La Cima, México. Biodiversity and Conservation 16:1055-1061. https://doi. org/10.1007/s10531-006-9062-5

Oliveras de Ita, A., and O. R. Rojas-Soto. 2006. A survey for the Sierra Madre Sparrow (Xenospiza baileyi), with its rediscovery in the state of Durango, Mexico. Bird Conservation International 16:25-32. https://doi.org/10.1017/S0959270905000687

Ortega-Álvarez, R., L. A. Sánchez-González, and H. Berlanga. 2015. Plumas de multitudes, integración comunitaria en el estudio $y$ monitoreo de aves en México. Comisión Nacional para el Conocimiento y Uso de la Biodiversidad, Distrito Federal, México.

Rzedowski, G. C., and J. Rzedowski. 2005. Flora fanerogámica del Valle de México. Instituto de Ecología, A. C., Comisión Nacional para el Conocimiento y Uso de la Biodiversidad, Pátzcuaro, México.

Sánchez-González, L. A., R. Ortega-Álvarez, G. Martínez Molina, and R. Calderón Parra. 2019. Informe final: conservación del Gorrión Serrano y su hábitat en el Tepozteco y Corredor Biológico Chichinautzin. Programa para la protección y restauración de ecosistemas y especies en riesgo (PROREST) 2019: componente de conservación de especies en riesgo. UNAM, CONANP, Ciudad de México, México.

Secretaría de Medio Ambiente y Recursos Naturales (SEMARNAT). 2010. Norma Oficial Mexicana NOM-059-
ECOL-2010, Protección ambiental-especies nativas de México de flora y fauna silvestres-categorías de riesgo y especificaciones para su inclusión, exclusión o cambio-lista de especies en riesgo. Diario Oficial de la Federación. SEMARNAT, Ciudad de México, México.

Sullivan, B. L., C. L. Wood, M. J. Iliff, R. E. Bonney, D. Fink, and S. Kelling. 2009. eBird: a citizen-based bird observation network in the biological sciences. Biological Conservation 142:2282-2292. https://doi.org/10.1016/j.biocon.2009.05.006

Vázquez de la Torre, R. J. 2015. Metodología para ajustar clasificaciones supervisadas de imágenes satélites, una contribución a la conservación del Gorrión Serrano (Xenospiza baileyi). Universidad Nacional Autónoma de México, Distrito Federal, México.
Editor-in-Chief: Keith A.Hobson Subject Editor: Jean-Pierre L.Savard

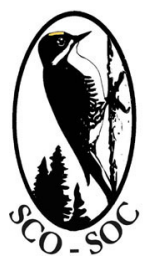

Sponsored by the Society of Canadian Ornithologists and Birds Canada

Parrainée par la Société des ornithologistes du Canada et Oiseaux Canada

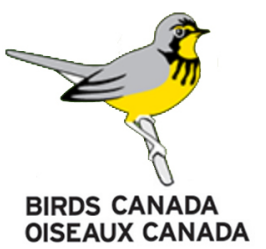

